\title{
Synthesis, Characterization, X-Ray Crystal Structures and Antibacterial Activity of Cobalt(III) Complexes Derived from 5-Bromo-2-((2-(phenylamino) ethylimino)methyl)phenol
}

\author{
Cheng Liu \\ School of Medicine, Huaqiao University, Quanzhou 362021, P. R. China \\ *Corresponding author: E-mail: liucheng_hqu@163.com
}

Received: 05-31-2021

\begin{abstract}
Two new and similar cobalt(III) complexes, $\left[\mathrm{CoL}_{2}\right] \cdot \mathrm{NO}_{3}(\mathbf{1})$ and $\left[\mathrm{CoL}_{2}\right] \cdot \mathrm{Cl}(\mathbf{2})$, where $\mathrm{L}$ is 5 -bromo-2-((2-(phenylamino)ethylimino)methyl)phenolate, have been synthesized and characterized by IR and UV-Vis spectra. Structures of the complexes were confirmed by single crystal X-ray determination. The Co atoms in the complexes are in octahedral coordination, with the donor atoms come from the two Schiff base ligands, viz. phenolate oxygen, and imino and amino nitrogen. The anions of the cobalt salts crystallized as counteranions in the complexes. The complexes were assayed for antibacterial activities by MTT method.
\end{abstract}

Keywords: Schiff base; cobalt complex; synthesis; X-ray diffraction; antibacterial activity

\section{Introduction}

Schiff bases due to their facile synthesis and interesting biological activities, have attracted considerable attention in inorganic and biological chemistry. In the past years, a number of Schiff base compounds have shown antifungal, antibacterial, antiproliferative, and antitumor activities. ${ }^{1}$ Schiff base compounds possess $\mathrm{N}$ and $\mathrm{O}$ donor atoms, are important ligands in coordination chemistry. A huge number of Schiff base complexes have been reported for their structures and interesting properties like magnetism, catalytic application, and biological activities. ${ }^{2}$ It is well known that some drug activities, when administered as metal complexes, are being increased. ${ }^{3}$ The field of medicine has witnessed an increase in the number of complexes with therapeutic value, for example Schiff base copper, nickel and zinc complexes are biological active agents, ${ }^{4}$ cobalt complexes with Schiff bases have shown effective antibacterial activities. ${ }^{5}$ The coordination chemistry of cobalt is of considerable interest since cobalt(II) and cobalt(III) complexes derived Schiff bases are reported to be biologically active. ${ }^{6}$ In addition, the Schiff bases synthesized from salicylaldehyde derivatives with halo atoms in the aromatic ring, showed effective antibacterial activities. ${ }^{7}$ Herein, we report the synthesis, characterization, and single crystal structures of two new cobalt(III) complexes, $\left[\mathrm{CoL}_{2}\right] \cdot \mathrm{NO}_{3}(\mathbf{1})$ and $\left[\mathrm{CoL}_{2}\right] \cdot \mathrm{Cl}(2)$, where $\mathrm{L}$ is 5 -bromo-2-((2-(phenylamino) ethylimino)methyl)phenolate. The antibacterial activity of the compounds against Gram-positive bacterial strains (B. subtilis, S. aureus and St. faecalis) and Gram-negative bacterial strains (E. coli, P. aeruginosa and E. cloacae) by MTT method was studied.

\section{Experimental}

\section{1. Materials and Physical Methods}

4-Bromosalicylaldehyde, $\quad \mathrm{N}$-phenylethane-1,2-diamine, cobalt nitrate and cobalt chloride were purchased from Aldrich. The solvents used in the synthesis and biological assay were commercial obtained and used as received. Elemental analyses for $\mathrm{C}, \mathrm{H}$ and $\mathrm{N}$ were performed on a Perkin-Elmer 2400 II analyzer. FT-IR spectra were recorded as $\mathrm{KBr}$ pellets on Bruker Tensor-27. UV-Vis spectra were recorded on Lambda 35 spectrophotometer. Single crystal X-ray diffraction was carried out with a Bruker Apex II CCD diffractometer. Molar conductivity was measured in methanol with a DDS-11A molar conductivity meter. 


\section{2. Synthesis of $\left[\mathrm{CoL}_{2}\right] \cdot \mathrm{NO}_{3}(1)$}

4-Bromosalicylaldehyde $(0.20 \mathrm{~g}, 1.0 \mathrm{mmol})$ and $\mathrm{N}$-phenylethane-1,2-diamine $(0.14 \mathrm{~g}, 1.0 \mathrm{mmol})$ were reacted in methanol $(30 \mathrm{~mL})$. The mixture was stirred at reflux for $30 \mathrm{~min}$, and cobalt nitrate hexahydrate $(0.29 \mathrm{~g}, 1.0$ $\mathrm{mmol}$ ) was added. After one hour stirring, the solution was cooled to room temperature, filtered, and with the filtrate kept still for slow evaporation. The diffraction quality block like brown single crystals that deposited over a period of 8 days were collected by filtration and washed with methanol. The yield was $0.16 \mathrm{~g}(42 \%)$. Anal. Calc. (\%) for $\mathrm{C}_{30} \mathrm{H}_{28} \mathrm{Br}_{2} \mathrm{CoN}_{5} \mathrm{O}_{5}$ : C, 47.58; $\mathrm{H}, 3.73 ; \mathrm{N}, 9.25$. Found (\%): C, 47.39; H, 3.82; N, 9.13. IR data $\left(\mathrm{KBr}, \mathrm{cm}^{-1}\right): 3155 \mathrm{w}$, 3054w, 2971w, 2933w, 2853w, 1650s, 1586s, 1520m, 1490w, $1427 \mathrm{~s}, 1382 \mathrm{~s}, 1325 \mathrm{w}, 1310 \mathrm{w}, 1291 \mathrm{~m}, 1196 \mathrm{w}, 1130 \mathrm{~m}$, $1077 \mathrm{w}, 1055 \mathrm{w}, 1038 \mathrm{w}, 943 \mathrm{w}, 913 \mathrm{~m}, 852 \mathrm{w}, 800 \mathrm{w}, 777 \mathrm{w}$, 770w, 755w, 693w, 604w, 561w, 470w. UV-Vis data [methanol, $\left.\lambda / \mathrm{nm}\left(\varepsilon / \mathrm{L} \cdot \mathrm{mol}^{-1} \cdot \mathrm{cm}^{-1}\right)\right]: 245(16,630), 263(15,820)$, 302 (9,870), $385(2,450), 495(243) \cdot \Lambda_{\mathrm{M}}\left(10^{-3} \mathrm{~mol} \mathrm{~L}^{-1}\right.$ in methanol): $128 \Omega^{-1} \mathrm{~cm}^{2} \mathrm{~mol}^{-1}$.

\subsection{Synthesis of $\left[\mathrm{CoL}_{2}\right] \cdot \mathrm{Cl}(2)$}

This complex was prepared with the similar method as described for complex $\mathbf{1}$, with cobalt nitrate hexahydrate replaced by cobalt chloride hexahydrate $(0.24 \mathrm{~g}, 1.0 \mathrm{mmol})$. The diffraction quality block like brown single crystals that deposited over a period of 5 days were collected by filtration and washed with methanol. The yield was $0.21 \mathrm{~g}$ (58\%). Anal. Calc. (\%) for $\mathrm{C}_{30} \mathrm{H}_{28} \mathrm{Br}_{2} \mathrm{ClCoN}_{4} \mathrm{O}_{2}$ : C, 49.31; H, 3.86; $\mathrm{N}$, 7.67. Found (\%): C, $49.43 ; \mathrm{H}, 3.81 ; \mathrm{N}, 7.58$. IR data $(\mathrm{KBr}$, $\mathrm{cm}^{-1}$ ): 3167w, 3047w, 2962w, 2891w, 2849w, 1648s, 1586s, $1519 \mathrm{~m}, 1489 \mathrm{w}, 1427 \mathrm{~s}, 1327 \mathrm{w}, 1291 \mathrm{~m}, 1202 \mathrm{w}, 1189 \mathrm{~m}$, $1124 \mathrm{~m}, 1079 \mathrm{w}, 1058 \mathrm{w}, 1040 \mathrm{w}, 943 \mathrm{w}, 913 \mathrm{~m}, 853 \mathrm{w}, 787 \mathrm{w}$, 770w, 757w, 701w, 693w, 600w, 561w, 466w. UV-Vis data [methanol, $\left.\lambda / \mathrm{nm}\left(\varepsilon / \mathrm{L} \cdot \mathrm{mol}^{-1} \cdot \mathrm{cm}^{-1}\right)\right]: 230(16,120), 248$ (16,530), 260 (16,400), 304 (9,720), 385 (1,810), 497 (225). $\Lambda_{\mathrm{M}}\left(10^{-3} \mathrm{~mol} \mathrm{~L}^{-1}\right.$ in methanol): $135 \Omega^{-1} \mathrm{~cm}^{2} \mathrm{~mol}^{-1}$.

\section{4. X-Ray Structure Determination}

Intensity data of the complexes were collected at 298(2) K on a Bruker Apex II CCD diffractometer using graphite-monochromated $\mathrm{MoK}_{\mathrm{a}}$ radiation $(\lambda=0.71073 \AA)$. For data processing and absorption correction the packages SAINT and SADABS were used. ${ }^{8}$ Structures of the complexes were solved by direct and Fourier methods and refined by full-matrix least-squares based on $F^{2}$ using SHELXL. ${ }^{9}$ The non-hydrogen atoms were refined anisotropically. The amino hydrogen atom were located from electronic density maps, and refined with $\mathrm{N}-\mathrm{H}$ distances restrained to $0.90(1)$ $\AA$. The remaining hydrogen atoms have been placed at geometrical positions with fixed thermal parameters. Crystallographic data of the complexes are summarized in Table 1. Selected bond lengths and angles are listed in Table 2.

Table 1. Crystallographic data and refinement details for the complexes

\begin{tabular}{lll}
\hline & $\mathbf{1}$ & $\mathbf{2}$ \\
\hline Chemical Formula & $\mathrm{C}_{30} \mathrm{H}_{28} \mathrm{Br}_{2} \mathrm{CoN}_{5} \mathrm{O}_{5}$ & $\mathrm{C}_{30} \mathrm{H}_{28} \mathrm{Br}_{2} \mathrm{ClCoN}_{4} \mathrm{O}_{2}$ \\
Molecular weight & 757.32 & 730.76 \\
Crystal color, habit & Brown, block & Brown, block \\
Crystal size, mm & $0.23 \times 0.22 \times 0.20$ & $0.26 \times 0.23 \times 0.23$ \\
Crystal system & Monoclinic & Monoclinic \\
Space group & $C c$ & $C c$ \\
Unit cell dimensions: & & \\
$a, \AA$ & $10.667(2)$ & $10.4703(11)$ \\
$b, \AA$ & $19.0095(16)$ & $19.0897(13)$ \\
$c, \AA$ & $15.1924(11)$ & $15.1449(12)$ \\
$\beta$, o & $100.151(1)$ & $103.973(1)$ \\
$V, \AA^{3}$ & $3032.5(7)$ & $2937.5(4)$ \\
\hline$Z$ & 4 & 4 \\
\hline$\rho_{\text {calcd }}$, g cm & \\
$\mu$, mm & -3 & 1.652 \\
$\theta$ Range collected, deg & 1.659 & 3.431 \\
$T_{\text {min }}$ and $T_{\text {max }}$ & 3.249 & $2.134-25.496$ \\
Reflections collected/unique & $2.143-25.493$ & 0.469 and 0.506 \\
Observed reflections & 0.522 and 0.563 & $7793 / 4102$ \\
$(I \geq 2 \sigma(I))$ & $7800 / 4645$ & \\
Data/restraints/parameters & & 3496 \\
$\mathrm{GOOF}$ on $F^{2}$ & 3526 & $4102 / 4 / 370$ \\
$R_{1}, w R_{2}(I \geq 2 \sigma(I))$ & $4645 / 4 / 394$ & 0.970 \\
$R_{1}, w R_{2}($ all data) & 0.983 & $0.0328,0.0603$ \\
\hline & $0.0556,0.1445$ & $0.0435,0.0644$ \\
\hline & $0.0740,0.1558$ & \\
\hline & & \\
\hline & & \\
\hline & & \\
\hline
\end{tabular}

Liu et al.: Synthesis, Characterization, X-Ray Crystal ... 
Table 2. Selected bond distances $(\AA)$ and angles $\left(^{\circ}\right)$ for the complexes

\begin{tabular}{lrr}
\hline & 1 & $\mathbf{2}$ \\
\hline Co1-O1 & $1.866(8)$ & $1.884(4)$ \\
Co1-O2 & $1.881(8)$ & $1.875(4)$ \\
Co1-N1 & $1.888(8)$ & $1.909(5)$ \\
Co1-N2 & $2.021(9)$ & $2.049(5)$ \\
Co1-N3 & $1.908(9)$ & $1.899(5)$ \\
Co1-N4 & $2.021(10)$ & $2.027(5)$ \\
O1-Co1-O2 & $90.7(4)$ & $89.79(18)$ \\
O1-Co1-N1 & $94.1(4)$ & $93.88(19)$ \\
O2-Co1-N1 & $86.6(3)$ & $86.12(18)$ \\
O1-Co1-N3 & $85.7(4)$ & $85.63(18)$ \\
O2-Co1-N3 & $95.3(4)$ & $95.34(19)$ \\
N1-Co1-N3 & $178.0(4)$ & $178.5(2)$ \\
O1-Co1-N2 & $177.7(4)$ & $176.9(2)$ \\
O2-Co1-N2 & $87.2(4)$ & $87.2(2)$ \\
N1-Co1-N2 & $84.9(4)$ & $85.3(2)$ \\
N3-Co1-N2 & $95.3(4)$ & $95.24(19)$ \\
O1-Co1-N4 & $88.4(4)$ & $89.39(19)$ \\
O2-Co1-N4 & $179.0(4)$ & $179.1(2)$ \\
N1-Co1-N4 & $93.9(4)$ & $93.6(2)$ \\
N3-Co1-N4 & $84.2(4)$ & $84.9(2)$ \\
N2-Co1-N4 & $93.7(4)$ & $93.6(2)$ \\
\hline
\end{tabular}

\section{5. Antibacterial Activity}

Antibacterial activity of the complexes was tested against $B$. subtilis, $S$. aureus, $S$. faecalis, $P$. aeruginosa, E. coli, and $E$. cloacae using MTT medium. The minimum inhibitory concentrations (MICs) of the compounds were determined by a colorimetric method using MTT dye. ${ }^{10} \mathrm{~A}$ stock solution of the compounds $\left(50 \mu \mathrm{g} \mathrm{mL}^{-1}\right)$ in DMSO was prepared and quantities of the compounds were incorporated in specified quantity of sterilized liquid medium. A specified quantity of the medium containing the compounds was poured into micro-titration plates. Suspension of the microorganism was prepared to contain approximately $10^{5} \mathrm{cfu} \mathrm{mL}^{-1}$ and applied to micro-titration plates with serially diluted compounds in DMSO to be tested, and incubated at $37^{\circ} \mathrm{C}$ for $24 \mathrm{~h}$ for bacteria. After the MICs were visually determined on each micro-titration plate, $50 \mu \mathrm{L}$ of phosphate buffered saline (PBS

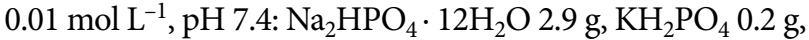
$\mathrm{NaCl} 8.0 \mathrm{~g}, \mathrm{KCl} 0.2 \mathrm{~g}$, distilled water $1000 \mathrm{~mL}$ ) containing 2 $\mathrm{mg} \mathrm{mL} \mathrm{m}^{-1}$ of MTT was added to each well. Incubation was continued at room temperature for $4-5 \mathrm{~h}$. The content of each well was removed, and $100 \mu \mathrm{L}$ of isopropanol containing $5 \%$ $1 \mathrm{~mol} \mathrm{~L}^{-1} \mathrm{HCl}$ was added to extract the dye. After $12 \mathrm{~h}$ of in-<smiles>NCCNc1ccccc1-c1ccc(Br)cc1O</smiles>

Scheme 1. The synthetic procedure for HL.<smiles>O=C(O[Na])c1ccc(NCC/N=C/c2ccc(Br)cc2O)cc1C(Cl)(Cl)Cl</smiles>

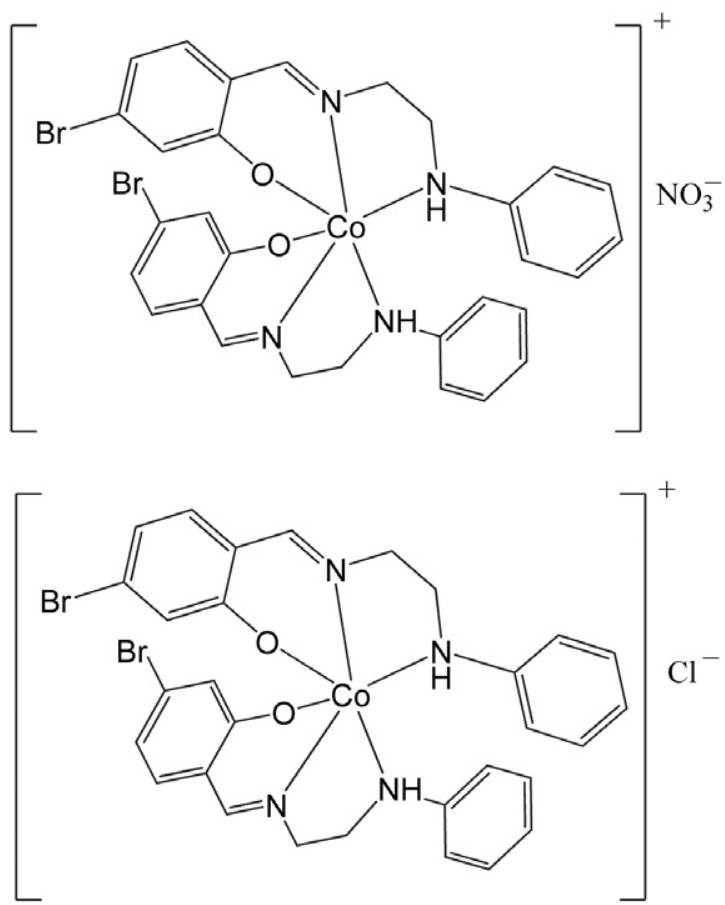

Scheme 2. The synthetic procedure for the complexes. 
cubation at room temperature, the optical density (OD) was measured with a microplate reader at $570 \mathrm{~nm}$.

\section{Results and Discussion}

\section{1. Chemistry}

The Schiff base HL was readily prepared by the reaction of 4-bromosalicylaldehyde and $\mathrm{N}$-phenylethane -1,2-diamine in methanol (Scheme 1). The complexes were prepared in a similar method, by the reaction of the Schiff base ligand with cobalt nitrate and cobalt chloride, respectively (Scheme 2 ). The conductivity values of the complexes $\left(128-135 \Omega^{-1} \mathrm{~cm}^{2} \mathrm{~mol}^{-1}\right)$ indicated that they are 1:1 electrolytes in methanol solution. ${ }^{11}$

\section{2. IR and UV-Vis Spectra Study}

The weak absorptions at 3155 and $3167 \mathrm{~cm}^{-1}$ for the infrared spectra of complexes $\mathbf{1}$ and $\mathbf{2}$ are assigned to $v_{\mathrm{N}-\mathrm{H}}$. The characteristic imine stretching for the complexes are observed at $1650 \mathrm{~cm}^{-1}$ for 1 and $1648 \mathrm{~cm}^{-1}$ for $2 .{ }^{12}$ The Schiff base ligand coordination through the phenolate oxygen is indicated by the absorption bands of the Ar-O bonds at about $1190 \mathrm{~cm}^{-1}$ in the complexes. ${ }^{13}$ In general, the infrared spectra of complexes $\mathbf{1}$ and $\mathbf{2}$ are similar to each other, except the absorption at $1382 \mathrm{~cm}^{-1}$ for the nitrate anion of complex $\mathbf{1} .^{14}$

The absorption spectral data of the complexes were measured in methanol solution. In both complexes, peaks between $240-250 \mathrm{~nm}, 260-310 \mathrm{~nm}$ and $380-390 \mathrm{~nm}$ are assigned to $\pi \rightarrow \pi^{\star}, n \rightarrow \pi^{*}$ and ligand to metal charge transfer transitions, respectively. ${ }^{12}$ In the visible spectra of both complexes, weak bands are observed at 495-497 nm.

\section{3. Structure Description of the Complexes}

Molecular structures of complexes $\mathbf{1}$ and $\mathbf{2}$ are shown in Figs. 1 and 2, respectively. Complex 1 contains a $\left[\mathrm{CoL}_{2}\right]^{+}$ cation and a nitrate anion. Complex 2 contains a $\left[\mathrm{CoL}_{2}\right]^{+}$ cation and a chloride anion. In the cation, the Co atom is coordinated by two phenolate oxygen $(\mathrm{O} 1, \mathrm{O} 2)$, two imino nitrogen $(\mathrm{N} 1, \mathrm{~N} 3)$ and two amino nitrogen $(\mathrm{N} 2, \mathrm{~N} 4)$ from two Schiff base ligands, forming octahedral geometry. In general, the coordination geometry around the Co atom in each complex displays only slight distortion. In both complexes, the bond lengths of $\mathrm{Co}-\mathrm{O}$ and $\mathrm{Co}^{-} \mathrm{N}$ are similar and range from $1.866(8)$ to $2.021(10) \AA$ for complex 1, and range from $1.875(4)$ to 2.049 (5) $\AA$ for complex 2 . The greatest deviations of the bond angles from those expected for an ideal octahedral geometry are $84.2(4)^{\circ}$ for $\mathrm{N} 3-\mathrm{Co} 1-\mathrm{N} 4$ and 95.3(4) ${ }^{\circ}$ for O2-Co1-N3 for complex 1, and $84.9(2)^{\circ}$ for N3-Co1-N4 and 95.3(2) for O2-Co1-N3 for complex 2. The remaining bond angles around the Co atoms are nearly close to the ideal values for octahedral geometry. Moreover, the coordinate bond values are comparable to those ob- served in similar Schiff base cobalt(III) complexes with octahedral geometry. ${ }^{15}$ The average deviation (0.033(4) $\AA$ for complex 1, 0.037(3) $\AA$ for complex 2) of the four donor atoms (O1, N1, N2, N3) and the displacement (0.001(2) ̊̊ for $\mathrm{Co} 1$ and 0.013(3) $\AA$ for Co2) of the Co atoms from the leastsquares planes defined by the four donor atoms indicate that the $\mathrm{ON}_{3}$ cavities afford almost perfect planes to the Co centers. The Schiff base ligands are twisted with dihedral angels between the benzene rings of $85.8(5)$ and $84.9(5)^{\circ}$ for complex $\mathbf{1}$, and 89.1(5) and 85.8(5) ${ }^{\circ}$ for complex 2 .

In the crystal structure of complex 1 (Fig. 3), the nitrate anions are linked to the complex cations through $\mathrm{N}-\mathrm{H} \cdots \mathrm{O}$ and $\mathrm{C}-\mathrm{H} \ldots \mathrm{O}$ hydrogen bonds. In the crystal structure of complex 2 (Fig. 4), the chloride anions are linked to the complex cations through $\mathrm{N}-\mathrm{H} \cdots \mathrm{Cl}$ and $\mathrm{C}-\mathrm{H}$... $\mathrm{Cl}$ hydrogen bonds. In addition, the molecules in both complexes are stack along the $a$ axis via $\pi \cdots \pi$ interactions among the rings $\mathrm{Co} 1-\mathrm{N} 1-\mathrm{C} 8-\mathrm{C} 9-\mathrm{N} 2, \mathrm{C} 1-\mathrm{C} 2-\mathrm{C} 3-$ C4-C5-C6, C10-C11-C12-C13-C14-C15 and C16-C17$\mathrm{C} 18-\mathrm{C} 19-\mathrm{C} 20-\mathrm{C} 21$.

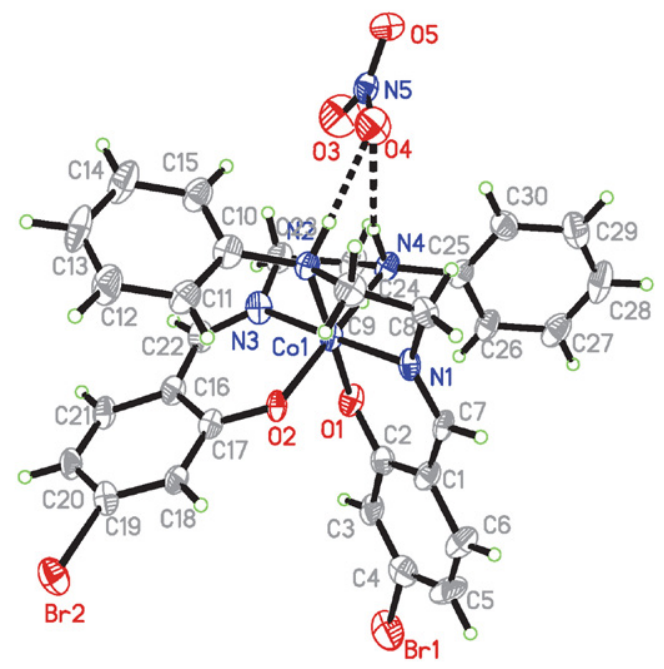

Fig. 1. Molecular structure of complex 1.

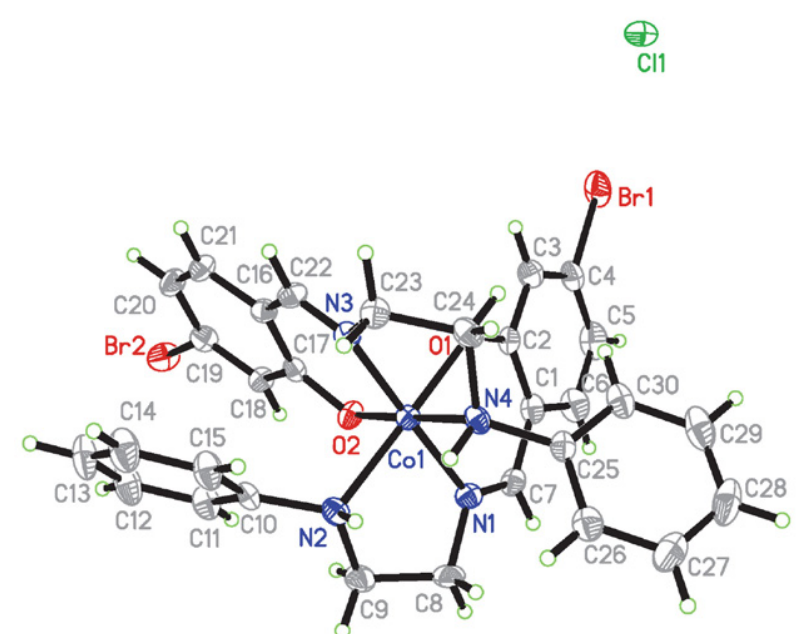

Fig. 2. Molecular structure of complex 2. 


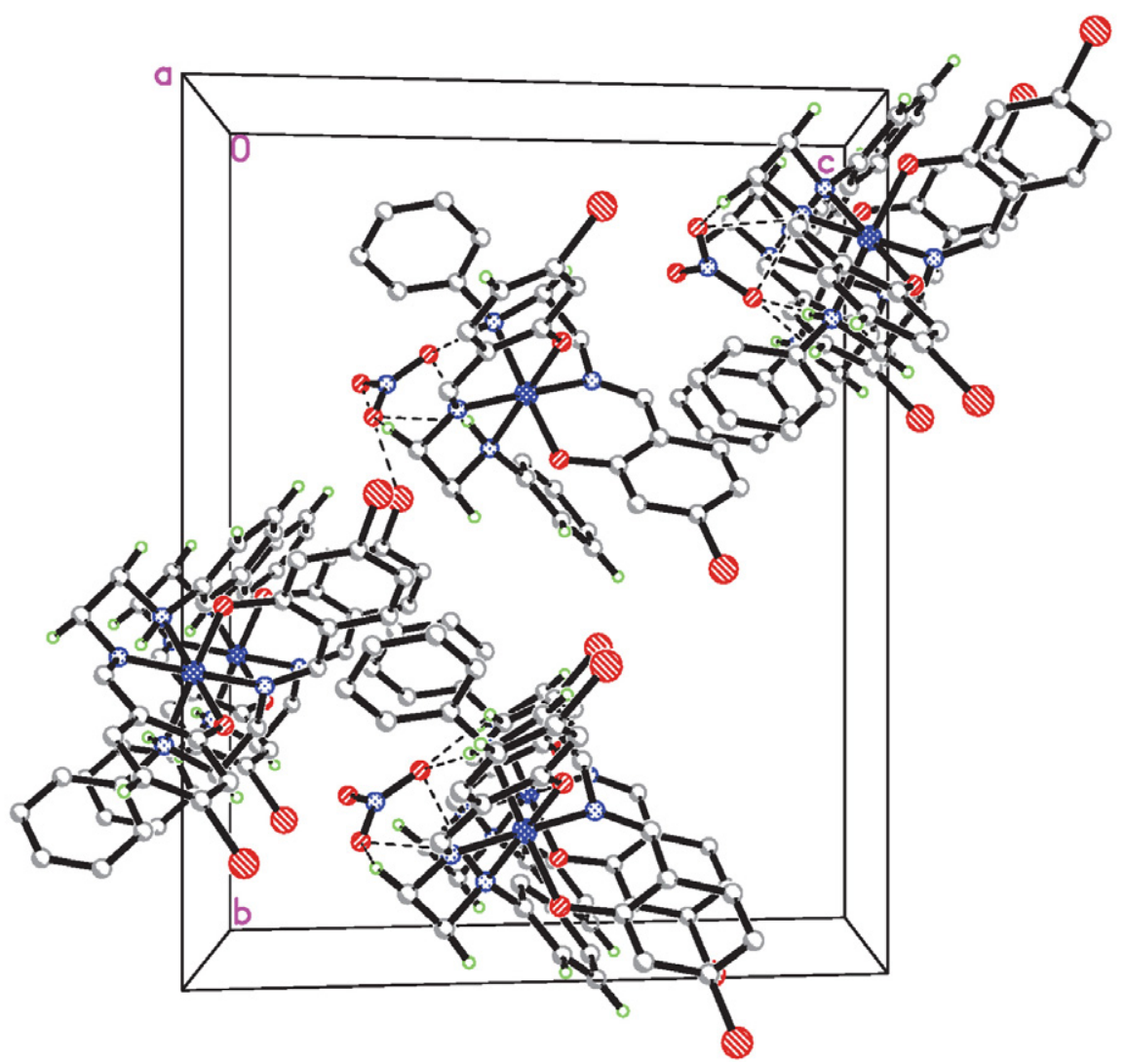

Fig. 3. Molecular packing diagram of complex 1, viewed along the $a$ axis. Hydrogen bonds are drawn as dashed lines.

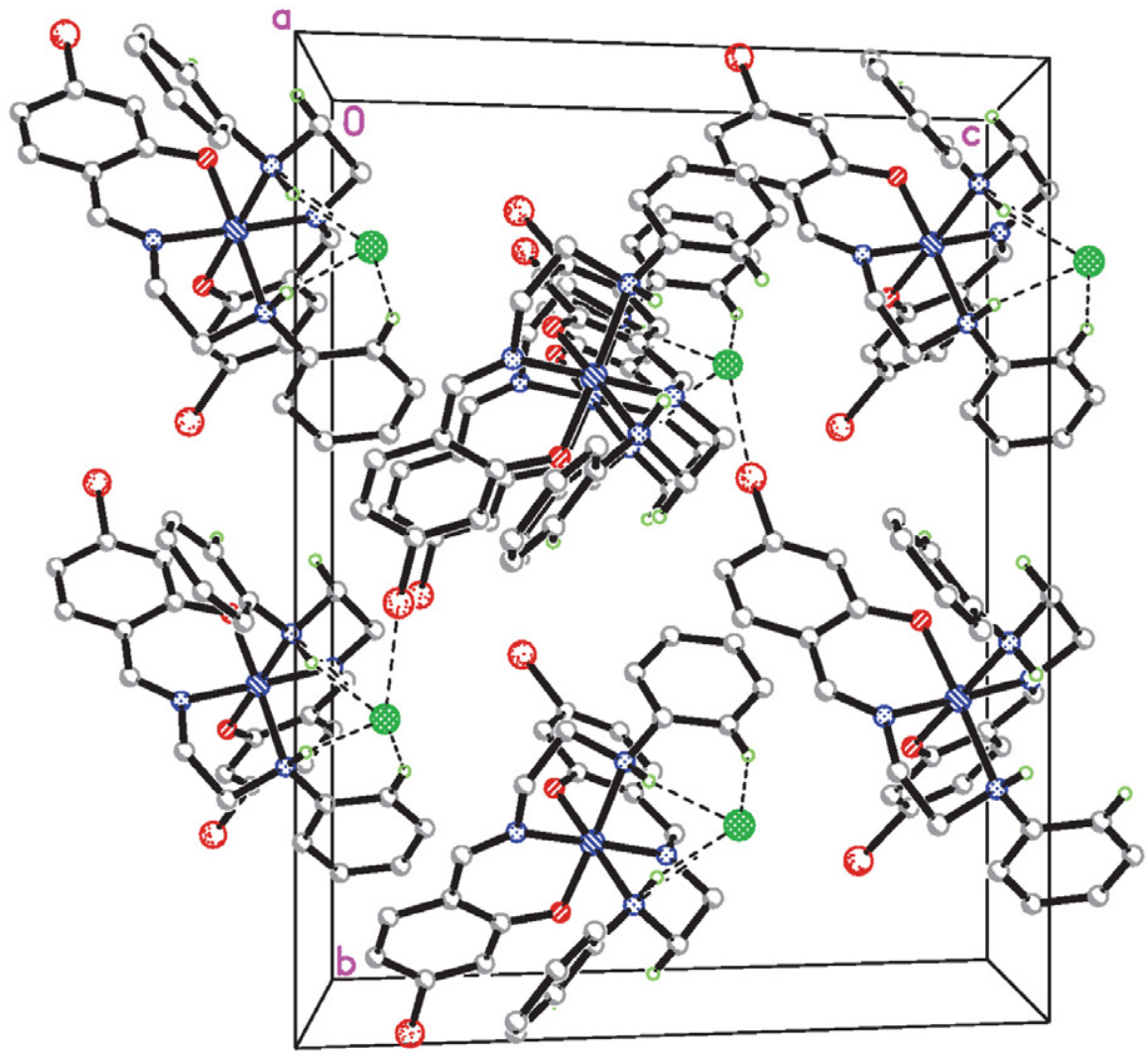

Fig. 4. Molecular packing diagram of complex 2, viewed along the $a$ axis. Hydrogen bonds are drawn as dashed lines. 


\section{4. Antibacterial Activity of the Compounds}

The cobalt complexes were screened for antibacterial activities against three Gram-positive bacterial strains ( $B$. subtilis, S. aureus, and St. faecalis) and three Gram-negative bacterial strains (E. coli, P. aeruginosa, and E. cloacae) by MTT method. The MICs of the compounds against the bacteria are presented in Table 3. Penicillin and Kanamycin were tested as reference drugs. The cobalt complexes have equal activities against all the bacterial strains. Both complexes showed strong activity against $B$. subtilis, S. aureus and E. coli $\left(\mathrm{MICs}=0.39-3.12 \mu \mathrm{g} \mathrm{mL} \mathrm{mL}^{-1}\right.$ ), weak activity against St. faecalis ( $\mathrm{MIC}=25 \mu \mathrm{g} \mathrm{m}^{-1}$ ), and no activity against $P$. aeruginosa and E. cloacae. Notably, both complexes have similar or better activity against $B$. subtilis, $S$. aureus and $E$. coli than the reference drugs.

Both complexes have stronger activities against $S$. aureus and $P$. aeruginosa than the cobalt(II) complexes with the Schiff bases, (4-X-2-\{[2-(2-pyridine-2-yl-ethylsulfanyl) ethylimino]methyl $\}$ phenol $(\mathrm{X}=$ methoxy $(\mathrm{OMe})$, phenylazo $\left(\mathrm{N}_{2} \mathrm{Ph}\right)$, bromo $(\mathrm{Br})$, nitro $\left.\left(\mathrm{NO}_{2}\right)\right),{ }^{16}$ and against B. subtilis, $S$. aureus and $E$. coli than the oxidovanadium(V) complexes with hydrazone ligands. ${ }^{17}$ The complexes have similar activities against $B$. subtilis, S. aureus and E. coli, but weak activities against St. faecalis, P. aeruginosa and E. cloacae when compared with the manganese complex with the Schiff base $N, N^{\prime}$-bis(3,5-dichlorosalicylidene)-1,4-butanediamine. ${ }^{18}$

\section{Conclusion}

Two new cobalt(III) complexes with the Schiff base 5-bromo-2-((2-(phenylamino)ethylimino)methyl)phenol have been synthesized and characterized. Crystal structures of the complexes are determined and described. Both complexes are mononuclear cobalt species with octahedral coordination. The anions of the cobalt salts used in the preparation of the complexes act as the counteranions of the final structures. Both complexes have effective antibacterial activities against B. subtilis, S. aureus and E. coli.

\section{Supplementary Materials}

The crystal data for the complexes have been deposited with the Cambridge Crystallographic Data Centre
(CCDC nos. 2086791 (1) and 2086793 (2); deposit@ccdc. cam.ac.uk or http://www.ccdc.cam.ac.uk).

\section{Acknowledgment}

The author acknowledges Huaqiao University for supporting this work.

\section{References}

1. (a) E. A. Fayed, R. R. E. Eldin, A. B. M. Mehany, A. H. Bayoumi, Y. A. Ammar, J. Mol. Struct. 2021, 1234, 130159;

DOI:10.1016/j.molstruc.2021.130159

(b) K. C. Gan, K. M. Sim, T. M. Lim, K. C. Teo, Lett. Org. Chem. 2020, 17, 191-198;

DOI:10.2174/1570178616666190724114741

(c) A. S. Hassan, H. M. Awad, A. A. Magd-El-Din, T. S. Hafez, Med. Chem. Res. 2018, 27, 915-927.

DOI:10.1007/s00044-017-2113-5

2. (a) N. Kordestani, H. A. Rudbari, A. R. Fernandes, L. R. Raposo, A. Luz, P. V. Baptista, G. Bruno, R. Scopelliti, Z. Fateminia, N. Micale, N. Tumanov, J. Wouters, A. A. Kajani, A. K. Bordbar, Dalton Trans. 2021, 50, 3990-4007; DOI:10.1039/D0DT03962D

(b) A. Patra, H. Puschmann, S. C. Manna, Polyhedron 2021, 201, 115146; DOI:10.1016/j.poly.2021.115146

(c) H. Kargar, A. A. Ardakani, M. N. Tahir, M. Ashfaq, K. S. Munawar, J. Mol. Struct. 2021, 1233, 130112;

DOI:10.1016/j.molstruc.2021.130112

(d) B. Cristovao, D. Osypiuk, B. Miroslaw, A. Bartyzel, Polyhedron 2020, 188, 114703;

DOI:10.1016/j.poly.2020.114703

(e) H. Mahmoudi, M. Bagherzadeh, S. Ataie, R. Kia, S. H. Moravej, M. Zare, P. R. Raithby, F. Ferlin, L. Vaccaro, Inorg. Chim. Acta 2020, 511, 119775.

DOI:10.1016/j.ica.2020.119775

3. L. A. Saghatforoush, F. Chalabian, A. Aminkhani, G. Karimnezhad, S. Ershad, Eur. J. Med. Chem. 2009, 44, 4490-4495. DOI:10.1016/j.ejmech.2009.06.015

4. (a) E. Lodyga-Chruscinska, M. Symonowicz, A. Sykula, A. Bujacz, E. Garribba, M. Rowinska-Zyrek, S. Oldziej, E. Klewicka, M. Janicka, K. Krolewska, M. Cieslak, K. Brodowska, L. Chruscinski, J. Inorg. Biochem. 2015, 143, 34-47; DOI:10.1016/j.jinorgbio.2014.11.005

Table 3. MICs $\left(\mu \mathrm{gL}^{-1}\right)$ of the compounds and related materials

\begin{tabular}{|c|c|c|c|c|c|c|}
\hline \multirow[t]{2}{*}{ Tested material } & \multicolumn{3}{|c|}{ Gram positive } & \multicolumn{3}{|c|}{ Gram negative } \\
\hline & B. subtilis & S. aureus & St. faecalis & P. aeruginosa & E. coli & E. cloacae \\
\hline $\mathrm{HL}$ & 12.5 & 6.25 & $>50$ & $>50$ & 12.5 & $>50$ \\
\hline 1 & 1.56 & 0.39 & 25 & $>50$ & 3.12 & $>50$ \\
\hline 2 & 1.56 & 0.39 & 25 & $>50$ & 3.12 & $>50$ \\
\hline Penicillin & 1.56 & 1.56 & 1.56 & 6.25 & 6.25 & 3.12 \\
\hline Kanamycin & 0.39 & 1.56 & 3.12 & 3.12 & 3.12 & 1.56 \\
\hline
\end{tabular}

Liu et al.: Synthesis, Characterization, X-Ray Crystal ... 
(b) Y.-F. Chen, L. Wei, J.-L. Bai, H. Zhou, Q.-M. Huang, J.-B. Li, Z.-Q. Pan, J. Coord. Chem. 2011, 64, 1153-1164; DOI:10.1080/00958972.2011.563846

(c) W. A. Zoubi, A. A. S. Al-Hamdani, S. D. Ahmed, Y. G. Ko, J. Phys. Org. Chem. 2018, 31, e3752; DOI:10.1002/poc.3752 (d) J. McGinley, M. McCann, K. J. Ni, T. Tallon, K. Kavanagh, M. Devereux, X. M. Ma, V. McKee, Polyhedron 2013, 55, 169-178; DOI:10.1016/j.poly.2013.03.023

(e) P. S. Mane, S. M. Salunke, B. S. More, T. K. Chondhekar, Asian J. Chem. 2012, 24, 2235-2238.

5. (a) M. Salehi, M. Amirnasr, S. Meghdadi, K. Mereiter, H. R. Bijanzadeh, A. Khaleghian, Polyhedron 2014, 81, 90-97; DOI:10.1016/j.poly.2014.05.049

(b) M. Ghosh, M. Layek, M. Fleck, R. Saha, D. Bandyopadhyay, Polyhedron 2015, 85, 312-319;

DOI:10.1016/j.poly.2014.08.014

(c) S. Mandal, T. Sen, U. Mandal, D. Bhunia, C. Rizzoli, D. Bandyopadhyay, J. Coord. Chem. 2019, 72, 3614-3624;

DOI:10.1080/00958972.2019.1704275

(d) G. Kalaiarasi, S. Dharani, S. R. J. Rajkumar, M. Ranjani, V. M. Lynch, R. Prabhakaran, Inorg. Chim. Acta 2021, 515, 120060. DOI:10.1016/j.ica.2020.120060

6. S. Esmaielzadeh, Z. Zare, L. Azimian, Bull. Chem. Soc. Ethiop. 2016, 30, 209-220. DOI:10.4314/bcse.v30i2.5

7. (a) B. K. Mallandur, G. Rangaiah, N. V. Harohally, Synth. Commun. 2017, 47, 1065-1070;

DOI:10.1080/00397911.2017.1309668

(b) L. Shi, H.-M. Ge, S.-H. Tan, H.-Q. Li, Y.-C. Song, H.-L. Zhu, R.-X. Tan, Eur. J. Med. Chem. 2007, 42, 558-564.

DOI:10.1016/j.ejmech.2006.11.010
8. G. M. Sheldrick, SAINT (version 6.02), SADABS (version 2.03), Madison (WI, USA): Bruker AXS Inc, 2002.

9. G. M. Sheldrick, Acta Crystallogr. 2008, A64, 112-122. DOI:10.1107/S0108767307043930

10. J. Meletiadis, J. Meis, J. W. Mouton, J. P. Donnelly, P. E. Verweij, J. Clin. Microbiol. 2000, 38, 2949-2956.

11. W. J. Geary, Coord. Chem. Rev. 1971, 7, 81-122. DOI:10.1016/S0010-8545(00)80009-0

12. L. Pogány, J. Moncol, M. Gál, I. Šalitroš, R. Boča. Inorg. Chim. Acta 2017, 462, 23-29. DOI:10.1016/j.ica.2017.03.001

13. Y.-M. Zhou, X.-R. Ye, F.-B. Xin, X.-Q. Xin, Trans. Met. Chem. 1999, 24, 118-120. DOI:10.1023/A:1006989707001

14. M. F. Iskander, T. E. Khalil, R. Werner, W. Haase, I. Svoboda, H. Fuess, Polyhedron 2000, 19, 1181-1191. DOI:10.1016/S0277-5387(00)00366-1

15. (a) D. Bandyopadhyay, M. Layek, M. Fleck, R. Saha, C. Rizzoli, Inorg. Chim. Acta 2017, 461, 174-182;

DOI:10.1016/j.ica.2017.02.018

(b) M. Ghosh, S. Mandal, M. Fleck, R. Saha, C. Rizzoli, D. Bandyopadhyay, J. Coord. Chem. 2018, 71, 4180-4193; DOI:10.1080/00958972.2018.1532080

(c) M. Hasanzadeh, M. Salehi, M. Kubicki, S. M. Shahcheragh, G. Dutkiewicz, M. Pyziak, A. Khaleghian, Trans. Met. Chem. 2014, 39, 623-632. DOI:10.1007/s11243-014-9841-x

16. L. A. Saghatforoush, F. Chalabian, A. Aminkhani, G. Karimnezhad, S. Ershad, Eur. J. Med. Chem. 2009, 44, 4490-4495. DOI:10.1016/j.ejmech.2009.06.015

17. H.-Y. Qian, Acta Chim. Slov. 2019, 66, 995-1001. DOI:10.4149/neo_2019_190112N36

18. H.-Y. Qian, N. Sun, Transition Met. Chem. 2019, 44, 501-506. DOI:10.1007/s11243-018-00296-X

\section{Povzetek}

Sintetizirali smo dva strukturno podobna kompleksa $\mathrm{Co}(\mathrm{III}),\left[\mathrm{CoL}_{2}\right] \cdot \mathrm{NO}_{3}(\mathbf{1})$ in $\left[\mathrm{CoL}_{2}\right] \cdot \mathrm{Cl}(\mathbf{2})$, kjer je $\mathrm{L}=5$-bromo-2-((2-(fenilamino)etilimino)metil)fenolat, ter produkta karakterizirali z IR in UV-Vis spektroskopijo. Strukture kompleksov smo določili $\mathrm{z}$ monokristalno rentgensko difrakcijo. Kobaltovi atomi v kompleksih so oktaedrično koordinirani, pri čemer so donorski atomi iz dveh ligandov: kisik iz fenolne skupine ter dušikova atoma iz imino in amino skupine. Anioni kobaltovih soli kristalizirajo kot protiioni. Antibakterijsko učinkovitost kompleksov smo preverili $\mathrm{z}$ metodo MTT.

Except when otherwise noted, articles in this journal are published under the terms and conditions of the Creative Commons Attribution 4.0 International License 